\title{
Correction to: Enablers and barriers to implementing care quality improvement program in nursing homes in China
}

Yinan Zhao ${ }^{1 \dagger}$, Lulu Liao ${ }^{1 \dagger}$, Hui Feng ${ }^{1,2,3^{*}}$, Huijing Chen ${ }^{1}$ and Hongting Ning ${ }^{1}$

\section{Correction to: BMC Geriatr 21, 532 (2021)}

https://doi.org/10.1186/s12877-021-02488-0

During the publication process of the original article [1] the following contribution statement was accidentally omitted:

- Yinan Zhao and Lulu Liao equally contributed to this work.

The publisher apologizes for the inconvenience caused. The original article [1] has been updated.

\section{Author details}

${ }^{1}$ Xiangya School of Nursing, Central South University, Changsha, Hunan, China.

${ }^{2}$ Xiangya-Oceanwide Health Management Research Institute, Central South

University, Changsha, China. ${ }^{3}$ National Clinical Research Center for Geriatric

Disorders, Xiangya Hospital, Changsha, China.

Published online: 03 January 2022

\section{Reference}

1. Zhao Y, Liao L, Feng H, et al. Enablers and barriers to implementing care quality improvement program in nursing homes in China. BMC Geriatr. 2021;21:532. https://doi.org/10.1186/s12877-021-02488-0.

The original article can be found online at https://doi.org/10.1186/s12877021-02488-0.

*Correspondence: feng.hui@csu.edu.cn

${ }^{\dagger}$ Yinan Zhao and Lulu Liao contributed equally to this work.

${ }^{3}$ National Clinical Research Center for Geriatric Disorders, Xiangya

Hospital, Changsha, China

Full list of author information is available at the end of the article

(c) The Author(s) 2021. Open Access This article is licensed under a Creative Commons Attribution 4.0 International License, which permits use, sharing, adaptation, distribution and reproduction in any medium or format, as long as you give appropriate credit to the original author(s) and the source, provide a link to the Creative Commons licence, and indicate if changes were made. The images or other third party material in this article are included in the article's Creative Commons licence, unless indicated otherwise in a credit line to the material. If material is not included in the article's Creative Commons licence and your intended use is not permitted by statutory regulation or exceeds the permitted use, you will need to obtain permission directly from the copyright holder. To view a copy of this licence, visit http://creativecommons.org/licenses/by/4.0/. The Creative Commons Public Domain Dedication waiver (http://creativeco mmons.org/publicdomain/zero/1.0/) applies to the data made available in this article, unless otherwise stated in a credit line to the data. 